\title{
The analysis of factors influencing the dynamics of lowland riverbed erosion downstream of the Jeziorsko reservoir dam (central Poland)
}

\author{
Agnieszka SMAGA ${ }^{1}$, Jędrzej WIERZBICKI ${ }^{2, *}$, Michał WIERZBICKI ${ }^{3}$, \\ Mateusz HÄMMERLING ${ }^{4}$ and Robert RADASZEWSKI ${ }^{2}$ \\ 1 INTERRA - Przedsiębiorstwo Geologiczne i Geotechniczne, os. Rzeczypospolitej 85/1, 61-392 Poznań \\ 2 Adam Mickiewicz University in Poznań, Institute of Geology, Faculty of Geographical and Geological Sciences, Bogumiła \\ Krygowskiego 12, 61-680 Poznań, Poland \\ 3 Regional Water Management Board - Poznań, Chlebowa 4/8, 61-003 Poznań, Poland \\ 4 Poznań University of Life Sciences, Department of Hydraulic and Sanitary Engineering, Piątkowska 94a, 60-649 Poznań,
} Poland

Smaga, A., Wierzbicki, J., Wierzbicki, M., Hämmerling, M., Radaszewski, R., 2007. The analysis of factors influencing the dynamics of lowland riverbed erosion downstream of the Jeziorsko reservoir dam (central Poland). Geological Quarterly, 61 (4): 926-933, doi: 10.7306/gq.13

\begin{abstract}
Increased riverbed erosion could recently be observed in close vicinity of hydrotechnical constructions in many lowland rivers. The immediate effect of erosion in this case is a very significant reduction of the riverbed level over a considerable distance, downstream of large reservoir dams. This process is influenced simultaneously by both hydraulics of river flow and geotechnical properties of soil eroded. The paper presents an analysis of parametric changes in the level of river bottom and grain size of bed material, and the relative density in the context of changes in hydrological conditions and diversity of engineering-geological conditions. As the result, a multiparametric model of erosional potential of riverbed sediments has been proposed, which can significantly help in proper planning of locations and construction of correction thresholds under given hydraulic conditions of the river.
\end{abstract}

Key words: river erosion, geotechnical parameters, hydrotechnical constructions, physical model.

\section{INTRODUCTION}

Building an impoundment structure on a river has a huge influence on the formation of its bed both above and below the structure (Nelson et al., 2013). Among many aspects of impoundment impact is interruption of the continuity of bed-load transportation, which causes imbalance in the riverbed dynamics. As a result, the transported material is deposited in the reservoir - mainly in its intake part (Przedwojski et al., 2008), while below the dam there is a process of increased erosion (Wierzbicki et al., 2008). It depends on water flow and geological conditions, means of weir exploitation, nature of work and barrage purpose, constructional solutions of the stilling basin and reinforcements below the weir, and further transport of the loosened bed load. The process of bed erosion is permanent and gives rise to local potholes directly below the outflow from the spillway (Guven and Gunal, 2008), as well as to a system-

* Corresponding author, e-mail: jwi@amu.edu.pl Received: February 17, 2017; accepted: August 23, 2017; first published online: XXXXX atic lowering of the bottom level on an increasingly longer stretch of the river (Parzonka and Kosierb, 2010). The process of erosion below impoundment is an additionally decisive factor in determining changes in bed-load graining of the riverbed. Water flowing out of water turbines and spillways discharges smaller material, causing the emergence of streambed armoring (Wierzbicki et al., 2008).

Erosion below an impoundment structure is an unfavourable process. Therefore, different steps are taken in order to reduce its negative effects. One of the ways is to build correction thresholds, which are aimed at reducing the longitudinal slopes of the water table in the river and, thus, slow the rate of the linear bed erosion. At the same time, however, a local pothole forms directly below the correction threshold. Soil erosion below the correction threshold is due to a significant increase in the kinetic energy of the flow and turbulence, compared to the flow in a natural stream (Zawadzki and Hämmerling, 2008).

The process of riverbed erosion does not only depend on the river flow but also on the sediment type that composes the river valley. These factors, together with the natural change of the longitudinal river profile, affect the varied nature of erosion in different parts of the river course. The impact of geology is clearly visible in mountainous and highland areas. It seems, however, that geology may be of vital importance also in the event of lowland river erosion, especially when the natural pro- 
file of the river changes as a result of raising hydrotechnical constructions (Dai and Liu, 2013).

Typical environmental problems related to the exploitation of waterway construction were presented by Bagiński (2007). An excellent example of riverbed erosion below the piling-up structures is the case of a dam on the Vistula River at Włocławek. The results of bathymetric measurements showed that the lowering of the bed and the water level downstream of the dam occurred over a distance of $\sim 30 \mathrm{~km}$. The greatest bed lowering occurred directly close to the dam. It reached a maximum value of $\sim 4.0 \mathrm{~m}$, and exceeded $2.5 \mathrm{~m}$ over a $9 \mathrm{~km}$ section. In addition, as a result of the described process, the water level decreased by an average of $2.30 \mathrm{~m}$, which caused an increase in the height of the reservoir water from the designed 11.8 to $14.1 \mathrm{~m}$ (Habel, 2007). Over a distance of $10 \mathrm{~km}$ downstream of the dam, the riverbed has been "cleaned" of sand and gravel deposits, reaching erosion-resistant clay and moraine clay. Then, the slow process of river cutting into these sediments started (Babiński and Habel, 2013). The construction of the next dam at Włocławek would limit the unfavourable processes taking place in the river. The construction of the next hydraulic project downstream of Włocławek was proposed several times, but its implementation was unfortunately suspended because of the economic crisis and protests from various environmentalist organizations (Majewski, 2015).

Susceptibility of sediment accumulated in a valley to the process of erosion can be identified on the basis of the spatial differentiation of geotechnical and hydraulic parameter values (Zakizadeh et al., 2013). There is a theoretical model of erosion rate of the riverbed composed of cohesive soil. However, non-cohesive soil has been found in the research area. Therefore, there was a need to create a model of erosion rate of non-cohesive soil, which is presented in this article.

\section{OBJECT CHARACTERISTICS}

The phenomenon of increased riverbed erosion and its adverse effects are particularly visible on the example of the Warta River below the Jeziorsko reservoir (central Poland). This reservoir formed as a result of damming the river channel with a dam at km 484.3 of the river course. Geoengineering and hydrological research was conducted on the Warta floodplain terrace along a stretch from the correction threshold no. 3 $(481 \mathrm{~km})$ to $\mathrm{km} 478.63$ of the river course (Fig. 1).

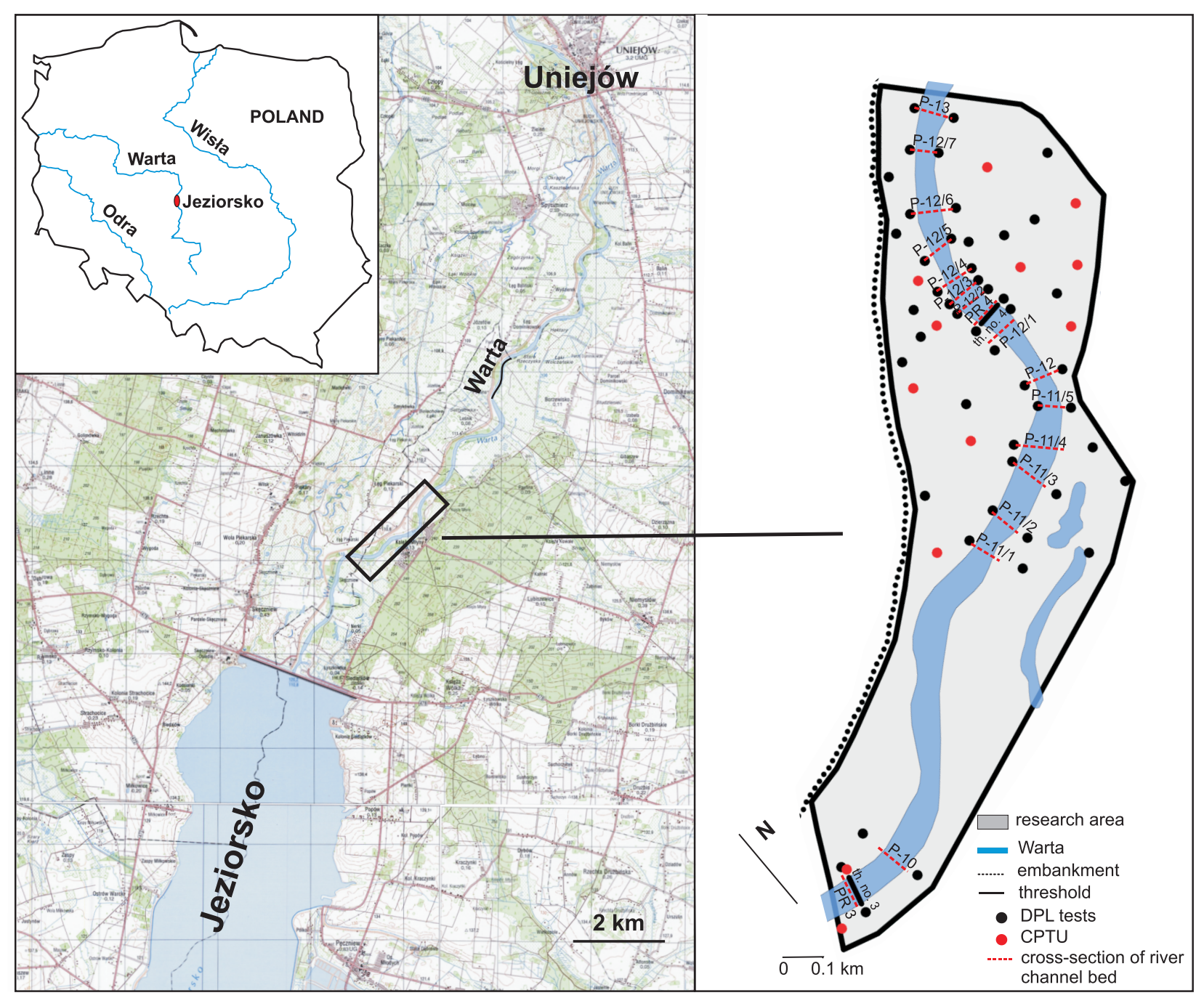

Fig. 1. Location of the research area

(topographic maps of the Warta, Poddębice, Dobra and Spyciemierz sheets, 1986, modified) 
During the first years of reservoir operation, an intense local erosion process below the weir spillway and the hydroelectric power station was observed. In the long term, it could have resulted in endangering the weir and water turbines stability. Between 1992 and 1994 in the near distance below the dam at km 483.830 and $\mathrm{km} \mathrm{483.710,} \mathrm{two} \mathrm{correction} \mathrm{sills} \mathrm{(nos.} \mathrm{1,} \mathrm{2)} \mathrm{were}$ built based on the construction of sheet piling. They provided stability of the water-table elevation at the medium and low levels as the ones observed in the river before the reservoir construction. However, below sill no. 2, there was a further lowering of the bottom and water table caused by an intense process of erosion (Wicher et al., 2002). In order to limit the effects of local and linear erosion, in 2005, two correction thresholds were built using rock mattresses no. 3 (km 480.902) and no. 4 (km 479.225). The mattresses have $35 \mathrm{~m}$ in length along the riverbed axis. Their construction resulted in a reduction of the dynamics of the linear erosion process below the reservoir on the stretch from the embankment dam to threshold no. 4. It caused slowing down of the lowering of the river bottom (and its lifting in some sections) and the previously observed inhibition of the increase in the characteristic diameter of bottom material (Wierzbicki et al., 2011). Although the process of erosion has decelerated along the section from the dam to threshold no. 4, it is still observed downstream the threshold no. 4. These changes are manifested in alterations of the bottom layout of the riverbed in both the longitudinal profile and cross-sections (Fig. 2).

The Jeziorsko reservoir operates according to an annual plan of water management. Hydrological analysis was prepared on basis of the outflow from the Jeziorsko reservoir. Therefore, the water flow strain below the reservoir is significantly levelled out (Fig. 3), with the exception of the maximum flows associated mainly with flooding episodes, which fall within the range of $100-360 \mathrm{~m} ; \times \mathrm{s}^{-1}$. In the study area, the lowest flows range between $15-40 \mathrm{~m} ; \times \mathrm{s}^{-1}$, while the average flows are from 34 to $80 \mathrm{~m} ; \times \mathrm{s}^{-1}$ (Perzyński, 2015). Figure 3 shows detailed charac- teristics of a hydrological catchment of the Warta River for the cross-section along the line of the dam.

In case of the sediment transport rate and balance in the reservoir, the daily, monthly and annual transport of bed load in the entrance section of the Jeziorsko reservoir was estimated on the basis of van Rijn (2007) formulas from 1984. Bed load is retained in the reservoir. Depending on the hydrograph of the water inflow at the inlet of the reservoir, the annual rate of sediment input to the reservoir is variable. In case of traction, the rate variesfrom $\sim 21,000$ to $\sim 54,000 \mathrm{~m}^{3} \times$ year $^{-1}$, and saltation from $\sim 67,000$ to $\sim 185,000 \mathrm{~m}^{3} \times$ year $^{-1}$ (Przedwojski, 2007). In the period of 25 years of reservoir exploitation, from 1991 to 2016 , the total input of bed load to the reservoir was about 3.15 million $\mathrm{m}^{3}$.

The results of sieve analysis of sediments from the Warta riverbed indicate that the riverbed deposits consist of non-cohesive soils with a wide spectrum of grain composition. The median particle diameter ranges from 0.3 to $1.5 \mathrm{~mm}$, and the maximum diameter is from 1 to $50 \mathrm{~mm}$.

\section{THE CONCEPT OF PROCESS MODEL DESCRIPTION OF NON-COHESIVE SOIL}

In literature we can find the most classic approach to the erosion in river. The following equation shows the relation between the tractive force generated on a riverbed (DuBoys equation) and the critical tractive force (Shield's equation) necessary to move a particle of a given size (Grossman, 2001):

$$
\tau=\rho \cdot g \cdot h \cdot I
$$

where: $\tau$ - shear stress [Pa], $\rho$ - water density $\left[\mathrm{kg} \mathrm{m}^{-3}\right], g$ - gravity acceleration $\left[\mathrm{ms}^{-2}\right], h$ - water depth [m], I - water slope [-].

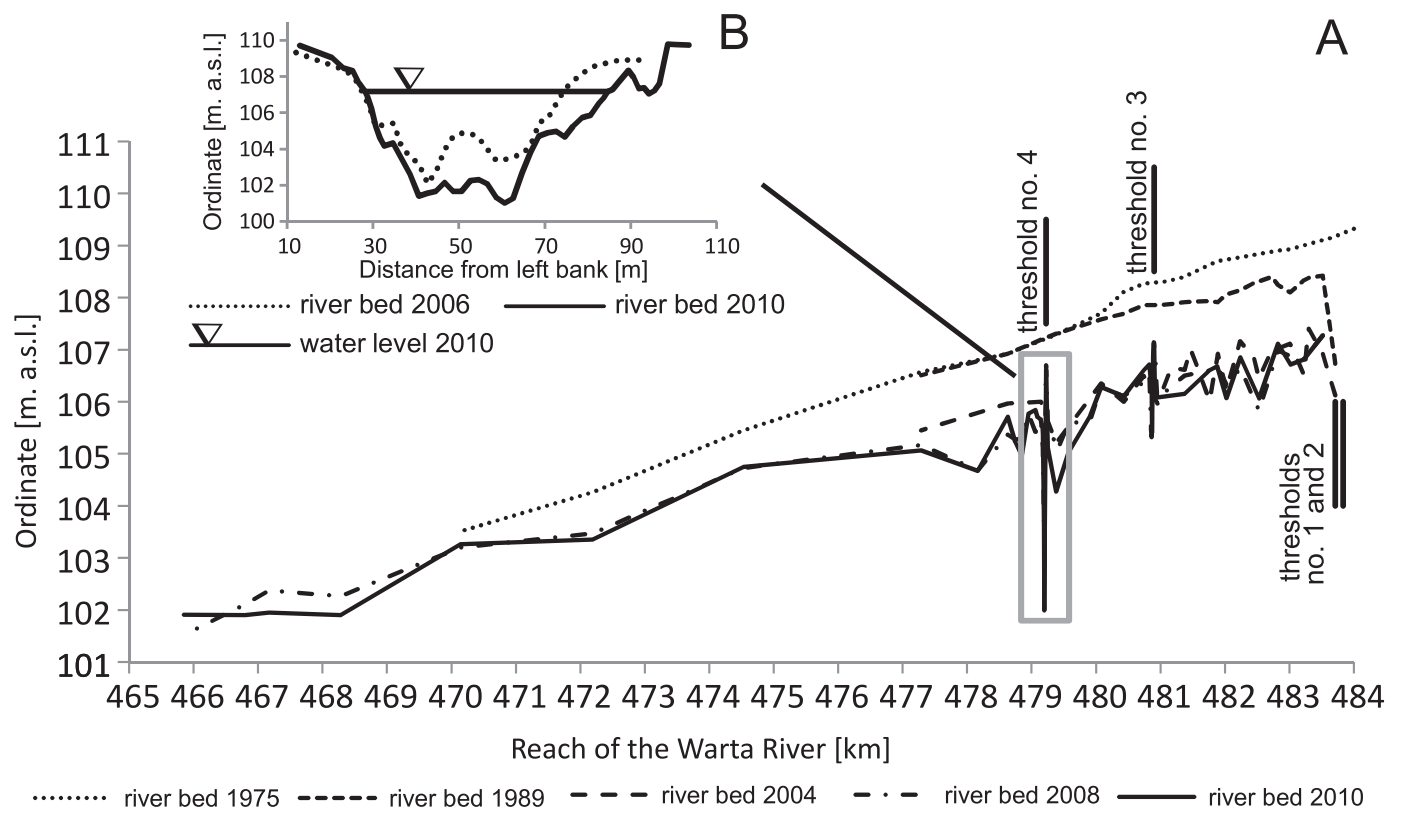

Fig. 2. Changes of riverbed levels in the Warta River downstream the of Jeziorsko reservoir (Hämmerling et al., 2014, modified)

A - longitudinal profile of the Warta River downstream of the dam; B - cross-section of river channel (perpendicular to the banks of the river) 


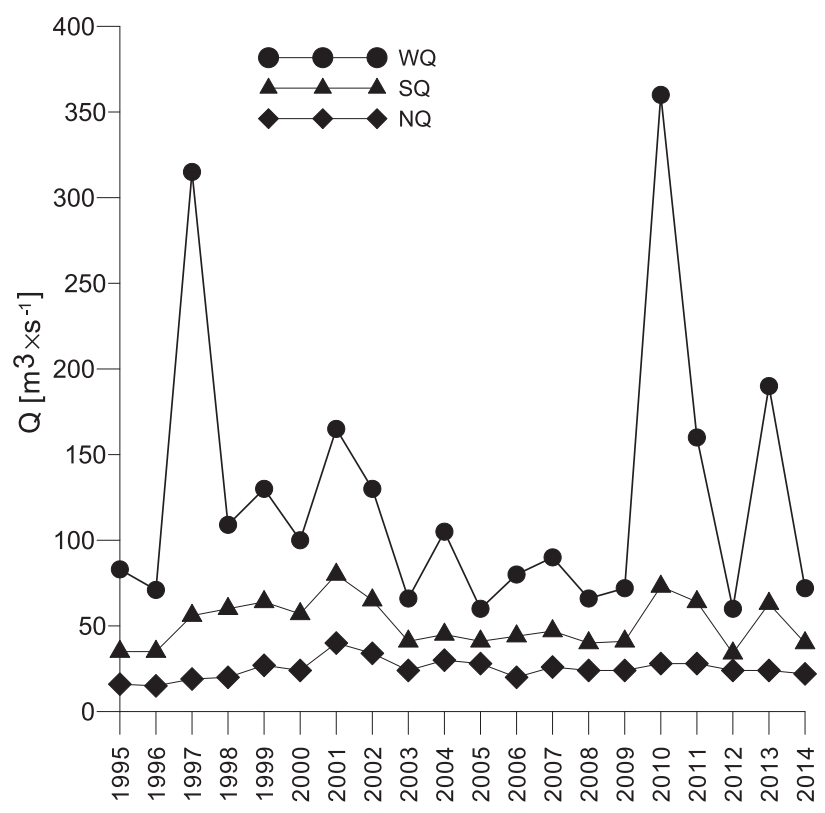

Fig. 3. Diagram of characteristic flows from 1995-2014 in a cross-sectional view along the line of the dam ( $\mathrm{km} \mathrm{484.300)}$

$W Q$ - high flow, $S Q$ - medium flow, NQ - low flow (based on Perzyński, 2015)

$$
\begin{gathered}
R e_{r}=\frac{u \cdot d}{v}<5.0 \quad S h=0.1 R e_{r}^{2 / 3} \\
5.0<R e_{r}=\frac{u \cdot d}{v}<20 \quad S h=0.033 \\
20<R e_{r}=\frac{u \cdot d}{v}<400 \quad S h=\frac{1}{55} R e_{r} \\
R e_{r}=\frac{u \cdot d}{v}>400 \quad \text { Sh }=0.059
\end{gathered}
$$

where: $R e_{r}-$ Reynolds number for a grain [-], Sh - Shields parameter [-], $v-$ kinematic viscosity coefficient $\left[\mathrm{m}^{2} \mathrm{~s}^{-1}\right], d-$ grain diameter $[\mathrm{m}], u-$ dynamic velocity $\left[\mathrm{ms}^{-1}\right]$.

The purpose of the research is to try to describe the process of erosion on the basis of varied geoengineering conditions. This correlation is possible due to observation of erosion below the Jeziorsko Reservoir, geological structure knowledge, and values of geotechnical parameters of the soil.

The erosion process can be referred to the situation of the loss of resistance to shear strength. Therefore, in view of the engineering geology, erosion of soils depends mainly on strength parameter values. However, since the process of erosion is not the perfect equivalent of shearing (there is also a process of loosening and detachment) for soil parameters responsible for its susceptibility to erosion, the following parameters can be distinguished:

- mechanical - cohesion $\left(c^{\prime}\right)$, friction angle $\left(\varphi^{\prime}\right)$, undrained shear strength $\left(s_{u}\right)$;

- physical - plasticity index $\left(I_{P}\right)$, relative density $\left(I_{D}\right)$, and those characteristic of graining distribution.

River erosion is observed in different kinds of soils, mostly in non-cohesive but also in cohesive (Briaud, 2008). Depending on riverbed geology, it is necessary to verify which geotechnical parameters should be taken into consideration.

Hydraulic soil erosion, which involves transportation of soil particles by the river current (Julian and Torress, 2006), is characterized mainly by two parameters: the critical shear stress and erosion rate (Ahmad et al., 2011; Jacobs et al., 2011).

Resistance of the subsoil to erosion is determined based on the critical shear stress $\left[\tau_{c}\left(\mathrm{~N} \times \mathrm{m}^{-2}\right)\right]$, which can be determined from the geotechnical parameters:

- non-cohesive soil:

- equation according to Briaud (2008):

$$
\tau_{c}=d_{50}
$$

where: $d_{50}$ - grain-size diameter, above which there is $50 \%$ of grains larger in diameter [mm].

- cohesive soil:

- equation according to Dunn (Yong Hui et al., 2008):

$$
\tau_{c}=0.01\left(\tau_{s}+180\right) \tan \left(30+1.73 I_{p}\right)
$$

where: $\tau_{\mathrm{s}}$ - shear strength of soil $\left[\mathrm{N} \times \mathrm{m}^{-2}\right] ; I_{P}-$ plasticity index $[-]$. - equation according to Otsubo and Muraoko (Yong Hui
et al., 2008)

$$
\tau_{c}=0.27 c^{0.56}
$$

where: $c-$ cohesion $\left[\mathrm{N} \times \mathrm{m}^{-2}\right]$.

Initiation of movement of soil particles starts when the shear stress induced by the flow $\left(\tau_{\mathrm{b}}\right)$ exceeds the value of the critical shear stress for erosion (Yong Hui et al., 2008; Ahmad et al., 2011).

Critical shear stress value, which is tantamount to the resistance of soil to erosion $\left(\tau_{c}\right)$, allows the calculation of erosion rate $(E)$ on the basis of the formula (Mitchener and Torfs., 1996; Yong Hui et al., 2008):

$$
E=M_{e}\left(\tau_{b}-\tau_{c}\right)
$$

where: $M_{e}$ - erosion coefficient (the value of the coefficient depends on soil parameters - Yong Hui et al., 2008; Jacobs et al., 2011).

$$
M_{e}\left(\rho_{d}, c_{v}, c, d_{50}\right)
$$

where: $\rho_{d}-$ volume density of soil skeleton; $c_{v}-$ consolidation coefficient; $c$-cohesion; $d_{50}$ - grain diameter corresponding to $50 \%$ finer.

Based on these relations, a theoretical model of erosion rate in cohesive soils was designed:

$$
E\left(\tau_{\mathrm{c}}, \tau_{\mathrm{b}}, \rho_{d}, c_{v}, c, d_{50}\right)
$$

Field test results, however, indicated a dominance of non-cohesive soil near the section of the Warta River floodplain terrace. Hence, there was a need to develop an experimental model in non-cohesive soil. The following assumptions were used:

- critical shear stress for erosion is a function of relative soil density $-\tau_{\mathrm{c}}\left(I_{D}\right)$, 
- cohesion equals zero $(c=0)$,

- volume density of grain skeleton is a function of relative soil density $-\rho_{d}\left(I_{D}\right)$,

- consolidation coefficient is a porosity function $-c_{v}(\mathrm{e})$,

- shear stress by flow is a function of the river flow $-\tau_{b}(Q)$,

- diameter $d_{90}$ reflects better the erosion potential of sediments studied than median particle diameter $d_{50}$.

Using these observations, a simplified model of erosion rate of non-cohesive soil in its general form was obtained:

$$
E\left(I_{D}, e, d_{50}, \mathrm{Q}\right)
$$

\section{TEST RESULTS}

In order to determine the geoengineering properties of deposits composing the flood terrace of the Warta River, drillings, light dynamic probing (DPL), and cone penetration tests (CPTU) were conducted. These studies were carried out on two banks of the river from the correction threshold no. $3(\mathrm{~km}$ 480.900 ) to $\mathrm{km} 478.630$ of the Warta course (Fig. 1). Locations of most DPL and CPTU were determined by hydraulic and hydrological studies. Probings are located at the banks of the river at the cross-section on the bottom of the Warta River bed.

Hydrogeological field research, which is included in the model, was conducted in 2006-2010. The study included measurements of the geometry of cross-sections of the riverbed, sampling of river sediment, and measurements of water flow velocity. Geometry of the cross-sections was defined using an echo sounder, a level steel cable stretched between two riverbanks. Sampling of the sediment took place using a sediment bailer. Detailed characteristics of sediment granulometry were described by Wierzbicki et al. (2011) who observed a variable but systematic increase of bottom sediment diameters resulting from the progressive erosion process downstream of the Jeziorsko reservoir (water leaving the reservoir removes fine material from the riverbed). The diameters and variability of riverbed sediment grains are greater along the section directly below the dam. In the far section of the river, differences in diameters are smaller. However, the analysis of the results of measurements performed after the stabilization sills had been built indicates that the size of the characteristic diameters was reduced. This may indicate the stabilization of the river channel and reduction of the dynamics of the erosion process.

For velocity measurements, a Hega 2 current metre and a Stream Pro ADCP device were used.

Drilling revealed mainly the presence of non-cohesive soil, with local thin inserts of organic soil. Therefore, the relative density of soil was deemed the leading parameter. The values of this parameter were based on the results of dynamic probings and cone penetration tests.

The results of DPL and CPTU were shown in probing profiles, which were juxtaposed with the corresponding cross-sections (Figs. 4 and 5). Correlation between the erosion rate and the relative density of soil was performed having assumed a horizontal spread of soil layers.

Data from cross-sections containing the riverbed bottom location within the period 2006 to 2010 were used to determine erosion rates in particular years. Erosion rate (E) was determined based on the arithmetic average of annual changes in the depth of the riverbed. Relative density, on the other hand, was determined from the equation:

$$
i_{D}=\frac{\sum_{i=1}^{n} I_{D_{n}} w_{n}}{\sum_{i=1}^{n} w_{n}}
$$

where: $I_{D_{n}}$ - the value of relative soil density in individual layers; $w_{n}$ - range of a separated layer - weight

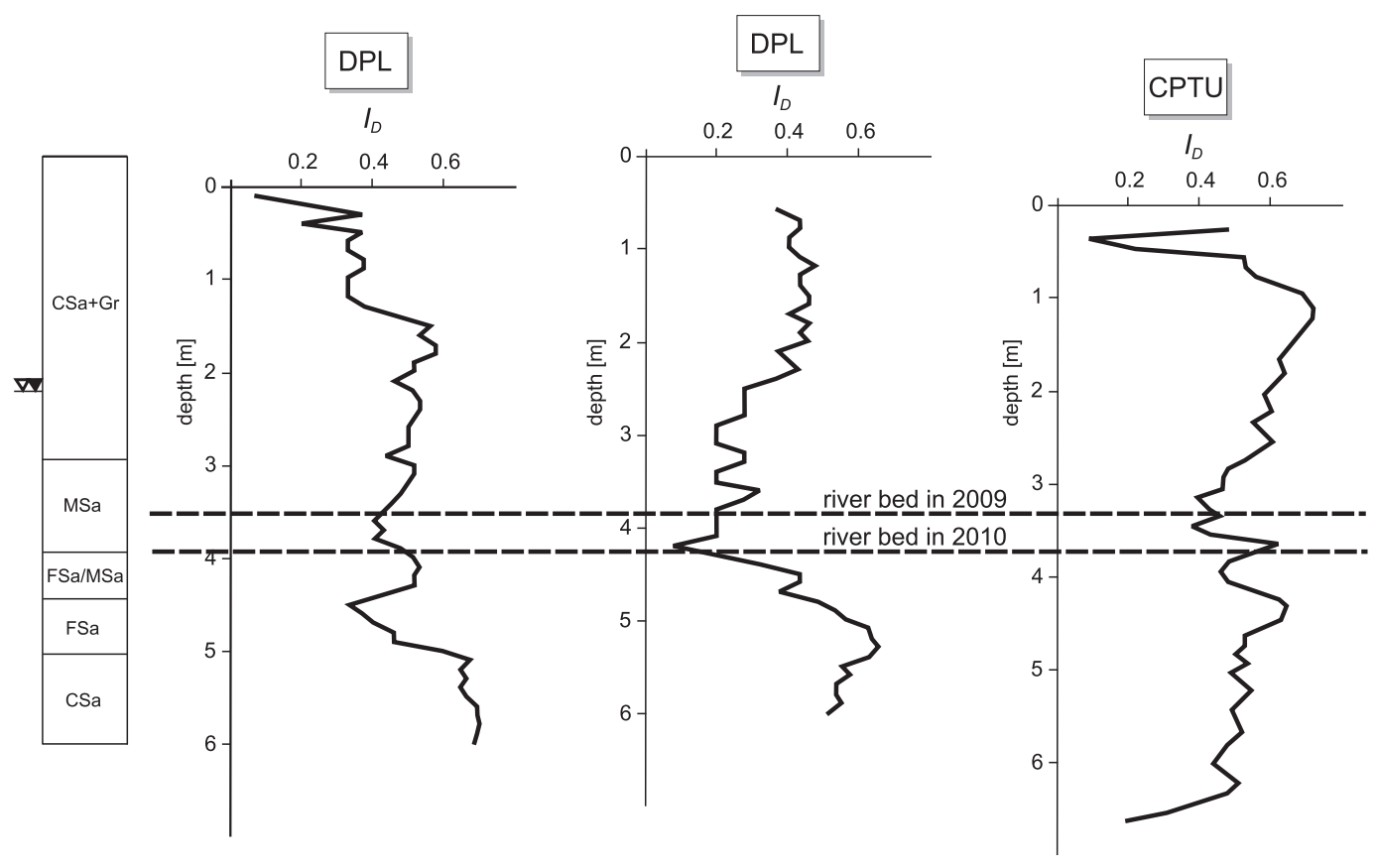

Fig. 4. Profiles of CPTU and DPL tests in cross-section $P 12 / 6$ with an average riverbed depth from 2009 and 2010 (Smaga, 2014, modified) 


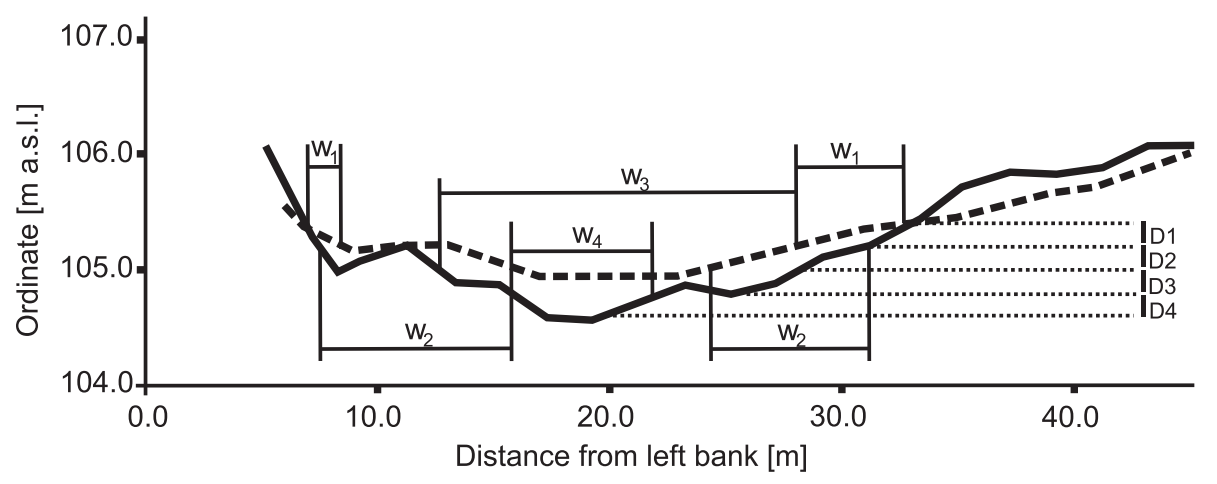

- E- river bed in 2009 river bed in 2010

Fig. 5. Scheme of data acquisition procedure (part of cross-section PR 4/6)

$\mathrm{W}_{1}-\mathrm{w}_{4}$ are the horizontal extents of $20 \mathrm{~cm}$ layers of eroded soils, which have assigned a specific $I_{D}$ value (relative density); $I_{D}$ values are read from the DPL and CPTU profiles (Fig. 4); The $w_{n}$ (there could be more layers in different cross-sections) extension is then used as a weight to determine the mean $I_{D}$ value for the eroded soil

Diagram of the procedure of data obtaining is shown in Figure 5. The field between cross-sections from a one-year period was divided into $20 \mathrm{~cm}$ wide strips. Each part was assigned an appropriate value of relative soil density $I_{D}$ and range $w_{n}$. With the obtained data, a weighted average of relative soil density was calculated. This procedure was used to interpret parameters in the following years in the PR 4-6 cross-section. For comparison, an arithmetic average was calculated, $I_{D}$ from a given depth range of the riverbed from particular years. The two averages did not differ significantly; therefore, the arithmetic average was applied for the interpretation of other cross-sections.

\section{ANALYSIS AND DISCUSSION}

The collected data from the analysed section of the Warta River made it possible to study the relationship between the measured hydraulic and geotechnical parameters, and the identified erosion rate, in accordance with the model assumptions (7). The relationship was investigated using basic statistic and geostatistic techniques, i.e. correlation and 2D interpolation performed using $\mathrm{R}$ and Surfer software, respectively.

In the first step of the analysis, the correlation of values of erosion rate and relative density for the observation points (eroded layer of sediments with a characteristic value of relative density after one year) was done. As a result, the scatterplot was obtained (grey dots in Figs. 6 and 7). In the next step to justify the distribution of points after correlation, the zones of values of river flow were imposed on the chart (Fig. 6). To obtain these zones, the authors used a kriging method in Surfer software. This juxtaposition allows noticing a dominant influence of flow values on erosion rate, and almost no such dependence in the case of relative density.

In the next stage, the correlation between erosion rate and relative density of the sediment was analysed, taking into account the sediment granulation variation (Fig. 7). In this case, there is a very clear common impact of the grain diameter and relative density on erosion rate. This confirms the general assumptions of the multiparametric model adopted in this study.

Having considered the above insights, the total model of correlation of erosion rate with flow size, relative density and median grain size of sediment was created (Fig. 8). Based on

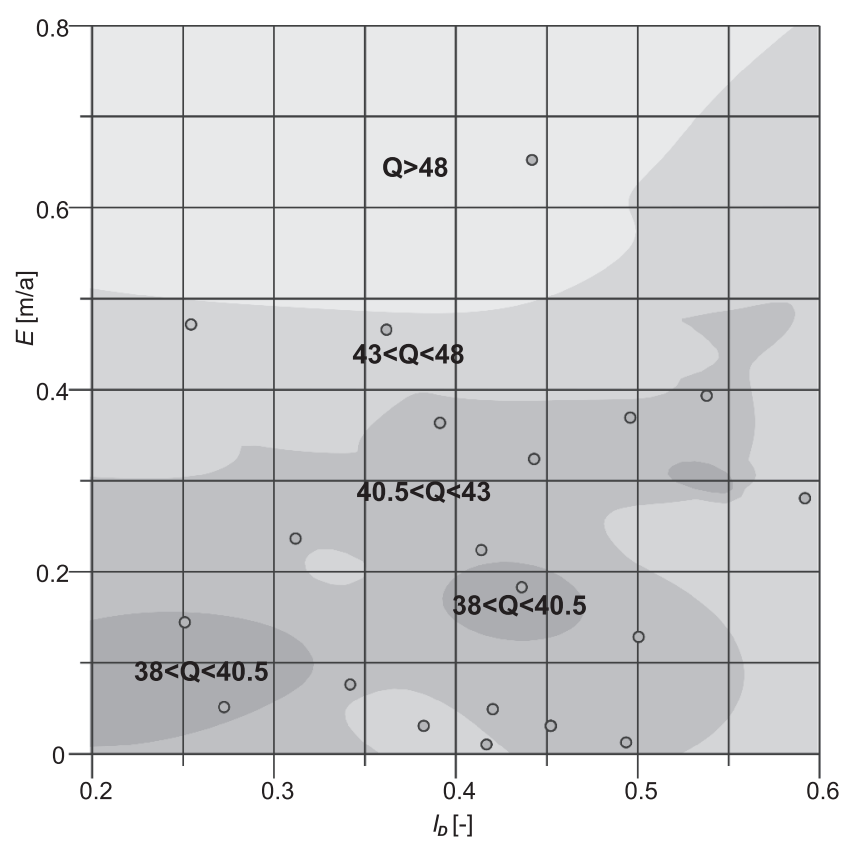

Fig. 6. Relationship between the erosion rate $(E)$ and relative density $\left(I_{D}\right)$ of riverbed on the background of characteristic flow (Q) during erosion

Grey dots are the observation from cross-sections with specific values of erosion rate, relative density, and river flow; distribution of these observations shows the correlation of erosion rate and relative density; ranges of river flow (in greyscale) are overlapped on the graph, as the attempt to explain the distribution of points after correlation

this model, it can be specified whether, in the given hydraulic conditions and with particular geotechnical properties of the sediment, erosion will occur at a specified rate. For example, in the case of the assumed river flow $\mathrm{Q}=38 \mathrm{~m} ; \times \mathrm{s}^{-1}$, erosion at an average rate of $0.2 \mathrm{~m} \times \mathrm{a}^{-1}$ will take place, but only when the sediment of median grain diameter $d_{90}=2.25 \mathrm{~mm}$ will have a relative density of $I_{D}<0.52$, or, for the same river flow, erosion of this rate will take place when the sediment will have a grain diameter of $d_{90}=5.25 \mathrm{~mm}$, but relative density will be $<0.33$. 


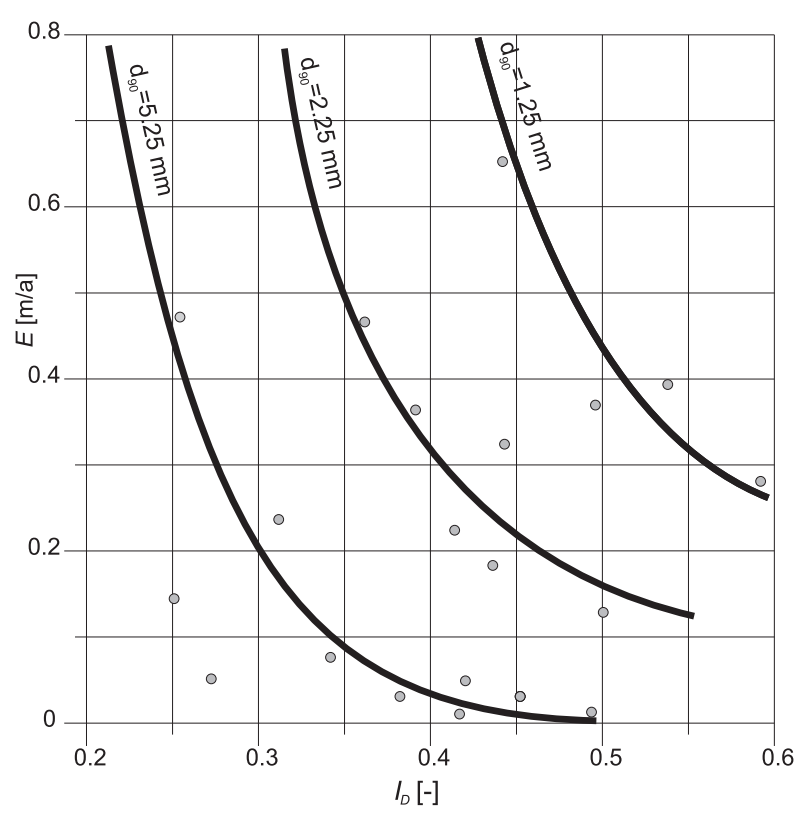

Fig. 7. Relationship between the erosion rate $(E)$ and relative density $\left(I_{D}\right)$ on the background of characteristic grain diameter corresponding to $90 \%$ finer of riverbed alluvia

In this case, to explain the distribution of observation points (grey dots), the authors took into consideration the values of characteristic diameter $\left(d_{90}\right)$; the black bold lines of equal $d_{90}$ diameter values were interpolated based on observation points (kriging technique in Surfer software was used)

There could be more than one solution, but if we verify the value of just one parameter, we can choose the right solution.

This model is not universal, but indicates the potential use of geotechnical parameters to determine the rate of river erosion. However, in order to create direct dependencies, research on this issue requires investigation in a laboratory channel, where both hydraulic and geotechnical parameters are measurable.

\section{CONCLUSIONS}

The analysis allowed the development of a model combining the observed erosion rate with hydrological characteristics of the river (characteristic flow) and geotechnical parameters of the bottom sediment (grain diameter and relative density). The proposed, general form of the model has been specified using correlative and interpolative techniques, which allowed determi-

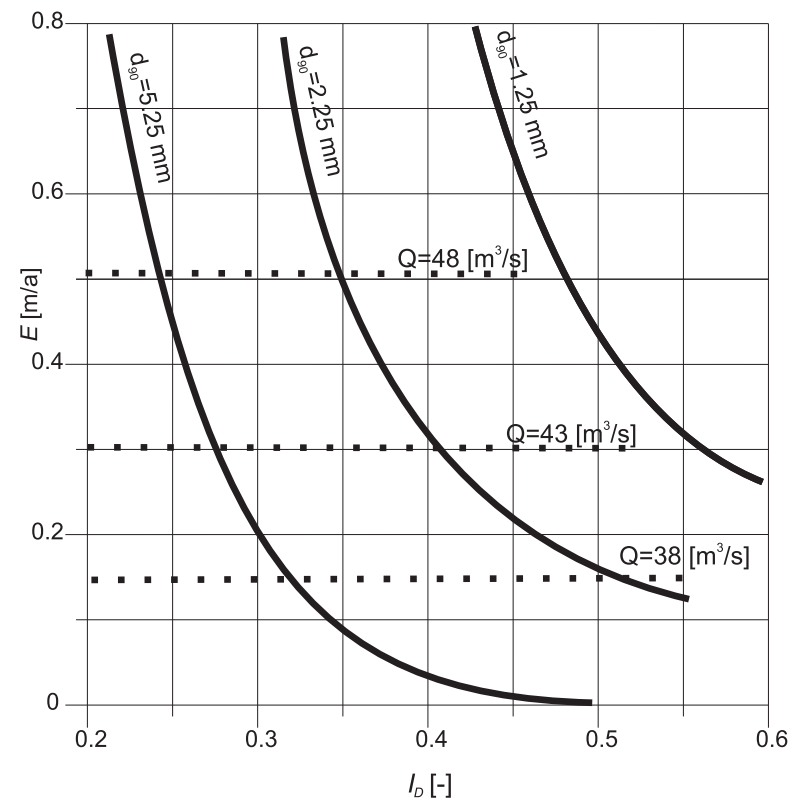

Fig. 8. The diagram of relationship between the riverbed erosion rate $(E)$, relative density $\left(I_{D}\right)$, characteristic grain diameter corresponding to $90 \%$ of finer, and characteristic flow

This graph is a result of the combination of the two models from Figures 6,7 , and shows a generalized model of the erosion rate for the valley composed of non-cohesive soils

nation of the significance of impact of individual factors on the erosion rate. The predominant factor is undoubtedly the flow value in the riverbed. However, particularly at lower flow values, the size of grains and the relative density of soil grow in importance. The obtained solution shows that the given erosion rate at the given water rate flow in the river will occur only when the overall condition of specifically small grain diameter and relative soil density will be met.

It seems appropriate to develop the presented model concept and its further detailing, and to present it in the form of a multiparametric equation. Such model development will allow a quantitative, not just quality-conditioned assessment of erosion below impoundment structures in the case of subsoil composed of non-cohesive soil.

Acknowledgements. The authors are grateful to K. Misiura, Anonymous Reviewer, and Prof. T.M. Peryt for their reviews and valuable comments that significantly improved the manuscript.

\section{REFERENCES}

Ahmad, M.F., Dong, P., Mamat, M., Wan Nik, W.B., Mohd, M.H., 2011. The critical shear stress for sand and mud mixture. Applied Mathematical Science, 5: 53-71.

Bagiński, L., 2007. Problems of the safety conditions of Włocławek dam (in Polish with English summary). Nauka Przyroda Technologie, 1: 1-12.

Babiński, Z., Habel, M., 2013. Impact of check dam on the hydromorphological processes below lowland reservoirs - illus- trated by the example of selected dams in Poland (in Polish with English summary). Journal of Health Sciences, 3: 52-55.

Briaud, J.L., 2008. Case histories in soil and rock erosion: Woodrow Wilson Bridge, Brazos River Meander, Normandy Cliffs, and New Orleans Levees. The 9th Ralph B. Peck Lecture. Journal of Geotechnical and Geoenvironmental Engineering, 134: 1-27.

Dai, Z., Liu, J.T., 2013. Impacts of large dams on downstream fluvial sedimentation: an example of the Three Gorges Dam (TGD) on 
the Changjiang (Yangtze River). Journal of Hydrology, 480: 10-18.

Grossman, M.J., 2001. Large floods and climatic change during the Holocene on the Ara River. Central Japan. Geomorphology, 39: 21-37.

Guven, A., Gunal, M., 2008. Prediction of scour downstream of grade-control structures using neutral networks. Journal of Hydraulic Engineering, 134: 1656-1660.

Habel, M., 2007. Erosion and accumulation processes of Vistula river below the Włocławku barrage (in Polish with English summary). Nauka Przyroda Technologie, 1: 1-9.

Hämmerling, M., Wierzbicki, M., Walczak, N., Zawadzki, P., Mazur, R., 2014. Investigations of local scour geometry changes downstream the stabilizing sills on the Warta river (in Polish with English summary). Nauka Przyroda Technologie, 8: 1-13.

Jacobs, W., LeHir, P., van Kesteren, W., Cann, F., 2011. Erosion threshold of sand-mud mixtures. Continental Shelf Research, 31: 14-25.

Julian, J.P., Torress, R., 2006. Hydraulic erosion of cohesive riverbanks. Geomorphology, 76: 193-206.

Majewski, W., 2015. The hydraulic project Włocławek: design, studies, construction and operation. Acta Energetica, 1: 33-40

Mitchener, H., Torfs, H., 1996. Erosion of mud/sand mixtures. Costal Engineering, 29: 1-25.

Nelson, N.C., Erwin, S.O., Schmidt, J.C., 2013. Spatial and temporal patterns in channel change on the Snake River downstream from Jackson Lake dam, Wyoming. Geomorphology, 200: 132-142.

Parzonka, W., Kosierb, R., 2010. Assessment of riverbed erosion process of middle Odra river on Malczyce-Ścinawa section. Studia Geotechnica et Mechanica, 32: 81-90.

Perzyński, M., 2015. Pomiar i modelowanie parametrów hydraulicznych w dolnym stanowisku budowli piętrzącej na rzece Warcie (in Polish). Msc. thesis, Poznań University of Life Sciences, Poznań.

Przedwojski, B., Wierzbicki, M., Wicher-Dysarz, J., Walczak, N., 2007. Emergency of flood upstream of the Jeziorsko reservoir (in Polish with English summery). Nauka Przyroda Technologie, 1: $1-12$.

Przedwojski, B., Dysarz, T., Wicher-Dysarz, J., Wierzbicki, M., 2008. Analiza wpływu czynników morfodynamicznych i wegetacyjnych na kształtowanie warunków hydraulicznych w cofkowej części nizinnych zbiorników wodnych (in Polish). Technical Report - Poznań University of Life Sciences. Poznań.

Smaga, A., 2014. Model of the erosion rate of non-cohesive subsoil (in Polish with English summary). In: Knowledge and Experiments in the Building Industry (ed. J. Bzówka): 181-188 Wydawnictwo Politechniki Śląskiej, Gliwice.

Van Rijn, L.C., 2007. Unified view of sediment transport by currents and waves. Journal of Hydraulic Engineering, 133: 649-667.

Wicher, J., Przedwojski, B., Wierzbicki, M., 2002. Changes of rating curve downstream of the Jeziorsko reservoir dam (in Polish with English summary). Roczniki Akademii Rolniczej w Poznaniu, 342, Melioracje i Inżynieria Środowiska, 23: 485-493.

Wierzbicki, M., Hämmerling, M., Przedwojski, B., 2008. The erosion process downstream the Jeziorsko reservoir on the Warta River (in Polish with English summary). Przegląd Naukowy Inżynieria i Kształtowanie Środowiska, 17: 136-145.

Wierzbicki, M., Hämmerling, M., Przedwojski, B., 2011. Wpływ budowy progów stabilizujących na kształtowanie się układu zwierciadła wody i dna poniżej zbiornika Jeziorsko (in Polish). Gospodarka Wodna, 6: 239-243.

Yong Hui, Z., Jin You, L., Hong Zhi, L., Jia Sheng, W., Bei Lin, F., Shi Ming, Y., 2008. Research on cohesive sediment erosion by flow: an overview. Science in China Series E: Technological Sciences, 51: 2001-2012.

Zakizadeh, B., Naeeni, O., Fakher, A., 2013. A probabilistic method to assess the subsurface erosion of non-cohesive soils. In: Geotechnical and Geophysical Site Characterization, 4 (eds. R.Q. Coutinho and P.W. Mayne). Taylor and Francis Group, London.

Zawadzki, P., Hämmerling, M., 2008. Changes of bed grain size distribution below hydraulic stucture (in Polish with English summary). Przegląd Naukowy Inżynieria i Kształtowanie Środowiska, 17: 146-154.

Dobra, mapa topograficzna 1:50,000 (in Polish), M-34-2-A, Geokart International Sp. z o.o. w Rzeszowie, OPGK Białystok, 1997.

Poddębice, mapa topograficzna 1:50,000 (in Polish), M-34-2-B, Geokart International Sp. z o.o. w Rzeszowie, OPGK Białystok, 1997.

Spycimierz, mapa topograficzna 1:25,000 (in Polish), 435.31/L, eds. Teresa Włodarczyk, OPGK Poznań, 1986.

Warta, mapa topograficzna 1:50,000 (in Polish), M-34-2-C, Geokart International Sp. z o.o. w Rzeszowie, OPGK Białystok, 1997. 